\title{
HDV-RNA and HBsAg Evolution during peg-IFN Treatment in Three HBV-HDV-HCV-HIV Coinfected Patients*
}

\author{
Anna Rosa Garbuglia ${ }^{1}$, Daniele Lapa ${ }^{1}$, Angela Testa ${ }^{2}$, Maria Rosaria Capobianchi ${ }^{1}$, \\ Ubaldo Visco-Comandini ${ }^{2 \#}$ \\ ${ }^{1}$ Laboratory of Virology, "L. Spallanzani” National Institute for Infectious Diseases, Rome, Italy; ${ }^{2}$ Clinical Department, "L. Spallan- \\ zani" National Institute for Infectious Diseases, Rome, Italy. \\ Email: "ubaldo.viscocomandini@inmi.it
}

Received June $16^{\text {th }}, 2012$; revised July $15^{\text {th }}, 2012$; accepted September $7^{\text {th }}, 2012$

\begin{abstract}
Background: Patients coinfected with HBV, HDV, HCV and HIV are usually excluded from clinical trials. Data on pegylated interferon treatment in this setting are limited, with predictive factors for HDV virologic success being unknown. Objectives: In this study we analyzed the time course of HDV viral load and HBsAg in HBV-HDV-HCV-HIV patients, who underwent pegylated alfa-2a interferon (peg-IFN) therapy for HDV infection between 2005 and 2009, with different virologic outcomes (no response, relapse or sustained response). Methods: Three patients were selected for virologic analysis, since complete clinical and laboratory data and stored residual blood samples, collected before/ during/after peg-IFN treatment were available. Plasma samples were retrospectively analyzed for HDV-RNA detection and quantitative HBsAg determination. Results: All patients were HCV-Ab positive, persistently HCV-RNA negative, and received a peg-IFN treatment curse $(180 \mathrm{mcg} /$ week) for 12 to 18 months. HIV and HBV viral loads remained undetectable due to underlying Tenofovir/Emtricitabine (TDF/FTC) treatment. Low baseline HDV-RNA and HBsAg levels were both observed in the patient with sustained viral response. A HDV-RNA decline greater than $2 \log _{10}$ at month 6 was observed in two of the three patients, both with compensated liver cirrhosis, achieving a viral clearance at the end of treatment. Conclusions: Although performed in few patients, this study suggests that a decline of HDV-RNA during treatment and low baseline quantitative HBsAg may be associated to HDV virologic response to peg-IFN in HIV-infected subjects, independently of fibrosis stage. If confirmed on larger patient number, these data may help to select those HDV-infected patients with a reliable chance to respond to prolonged peg-IFN treatment and suggest the importance of quantitative HBsAg monitoring in this setting.
\end{abstract}

Keywords: Delta Hepatitis; HIV Infection; Interferon Treatment; HDV Viral Load; Quantitative HBsAg

\section{Introduction}

HDV-positive is the most aggressive form of chronic viral hepatitis, with fast progression to liver cirrhosis when associated to HIV or HCV infection [1]. In HIVinfected patients (HIV+), the prevalence of anti-delta IgG antibodies (HDV-Ab) among HBsAg carrier varies from $15 \%$ to $50 \%$ in different studies, with most patients being viremic for HDV (HDV-RNA+) [2].

Administration of pegylated Interferon ( $\mathrm{pIFN}$ ) for

\footnotetext{
"Author contributions: A. R. Garbuglia, M. R. Capobianchi and U. Visco-Comandini designed research; A. R. Garbuglia and D. Lapa performed laboratory work; A. R. Garbuglia, A. Testa and U. ViscoComandini analyzed data; A. R. Garbuglia and U. Visco-Comandini wrote the article. Supported in part by: grants from Italian Ministry of Health, Fondi Ricerca Corrente and Ricerca Finalizzata.

${ }^{*}$ Corresponding author.
}

longer than 12 - 18 months has been shown to be relatively effective in HIV-uninfected subjects, with around $25 \%$ of sustained virological response (SVR) to HDV [3]. On the contrary, only anecdotal cases with sustained response have been described in chronic HDV+/HIV+ [4], since multiple coinfected patients are generally excluded from clinical trials. Therefore, optimal treatment schedules are uncertain and no studies have examined the efficacy of peg-IFN in this setting.

HDV-RNA quantification has been recently established, based on RT-real time PCR, and two virological parameters have been suggested to be correlated to pIFNinduced SVR to HDV in HIV-uninfected individuals [5]: the HDV-RNA decline during treatment (similarly to what is seen with HCV [6]), and the progressive decrease of HBsAg level in serum [7]. Since no information re- 
garding viral- or patient-associated sustained HDV clearance during pIFN treatment in $\mathrm{HBV} / \mathrm{HDV} / \mathrm{HCV} / \mathrm{HIV}$ coinfected patients is available, we decided to review all the HDV/HIV cases treated with peg-IFN between 2005 and 2009 at our Institution.

Our small case-series represents the first accurate description of the evolution of multiple viral parameters and of biochemical markers during peg-IFN treatment in this setting, with known long term outcome for HDV infection.

\section{Material and Methods}

\subsection{Study Population}

Forty-seven patients followed at our Institution between 2005 and 2009, with positive serum HBsAg and both HIV-HDV positive antibodies, were reviewed. Twentynine were viremic for HDV and eight of them underwent a peg-IFN treatment course during this period. Four of the treated subjects suspended peg-IFN before the sixth month without clearing HDV-RNA. Another patient persistently cleared HDV-RNA, but was excluded from the analysis, due to limited clinical information and lack of stored samples.

The remaining three patients, indicated in the present study as \#A, \#B and \#C, had both complete clinical information (including baseline liver biopsy or/and Fibro$\operatorname{scan}^{\circledR}$ value) and stored residual serum samples available, and were selected for retrospective analysis.

Liver fibrosis staging was obtained using the Metavir scoring system on adequate ( $>7$ complete portal spaces) liver biopsy specimen performed within 6 months before peg-IFN treatment (\#A and \#B), or by measuring the liver stiffnes with Fibroscan ${ }^{\circledR}$ (Echosens, Paris) in patient \#C and translated to Metavir score using the cut-off of $>15$ Kilo Pascal (KPa) for cirrhosis.

All three patients were males, former i.v. drug users, with positive antibodies against hepatitis $\mathrm{C}$ virus (HCV$\mathrm{Ab}$ ) and persistently negative HCV-RNA. All had undetectable HIV and HBV viral loads due to ongoing antiretroviral treatment (TDF/FTC as backbone plus a third drug) and were considered fully compliant.

Adherence of patients to ARV and peg-IFN therapy was routinely assessed by a structured questionaire used at our Institution.

\subsection{HDV RNA Detection}

Fourty-two frozen plasma samples from \#A, \#B, \#C (range 9 to 15 for each, including at least: one sample collected before, and samples collected at peg-IFN suspension, 6 and 12 months thereafter), were analysed. All samples were analyzed for qualitative HDV-RNA determination by seminested RT-PCR as previously described
[8], with a sensitivity of $400 \mathrm{HDV}$ RNA equivalents/ml. HDV genotype was determined by direct sequencing of the nested PCR products and aligned by using returned results from GeneBank's on-line BLAST server (http://www.ncbi.nlm.nih.gov/BLAST/).

\subsection{Quantification of HDV-RNA by Real Time PCR}

In all sera samples with positive result in the HDV qualitative assay, the level of HDV-RNA was determined as previously described [5]. Briefly, $10 \mu \mathrm{l}$ of cDNA were employed in real-time PCR in the same condition described by Le Gal et al., only the Delta-P (probe) 5'-FAM-ATGCCCAGGTCGGAC-MGB-3' was employed. As quantification standard, synthetic RNA was prepared by a cloned HDV cDNA with RiboMax-RNA production Kit (Promega, WI, USA); then RNA standard was quantified by optical density. The quantification curve was based on serial dilution of the RNA standard, retrotranscribed in the same conditions of patient RNA samples. According to the dilution factors during RNA extraction of samples and RT procedure, the sensitivity was $1000 \mathrm{HDV}-\mathrm{RNA}$ equivalent/ml and linearity was from $10^{3}$ to $10^{7}$ (correlation coefficient $=0.99$ ).

\subsection{Laboratory and Serological Study}

For quantitative HBsAg determination, the Abbott ARCHITECT Kit (Abbott Diagnostics, Abbott Park, IL, USA) was employed (dynamic range of 0.05 - 250 $\mathrm{IU} / \mathrm{ml})$. Samples with values above $250 \mathrm{IU} / \mathrm{ml}$ were diluted 1:10 and 1:100 and retested (maximum authorized dilution 1:999).

Complete virology assessment, CD4+T-cell counts, biochemistry, and antiretroviral (ARV) treatment data were obtained from laboratory or pharmacy database, respectively.

\subsection{Virological Definitions}

Sustained Virological Response (SVR): was defined as undetectable ( $<400$ equivalents/ml) serum HDV RNA on samples collected at completion of peg-IFN treatment course, and both 6 and 12 months thereafter.

Relapse (ETR-R): was defined as undetectable serum HDV-RNA on the sample collected at the end of pegIFN treatment, but detectable HDV RNA in any of the following samples.

Viral Non Response (NR): was defined as a detectable HDV-RNA at the completion of peg-IFN treatment course.

\section{Results}

Clinical and demographic data from \#A, \#B and \#C at 
the moment of peg-IFN start, are reported in Table 1. The patients received a peg- $\alpha 2$ aIFN treatment course (180 mcg/Week) for 12 to 18 months. The treatment was generally well tolerated from hematologic point of view, without need of dose reduction in any of the patients. However, peg-IFN was discontinued after 12 months in patient \#B, due to relevant psychiatric side effect. Interestingly, no substantial decline in absolute CD4 counts was observed during treatment in all patients.

All patients were infected with HDV-genotype 1 .

Virology results during and after peg-IFN are depicted in Table 2, together with the final HDV-infection outcome for each subject. HIV-RNA and HBV-DNA remained undetectable during whole peg-IFN course and up to 12 months thereafter in all three subjects.

HIV and HBV viral loads, tested every third month on fresh samples between 2005 and 2009, remained undetectable in the three patients, as a result of underlying Tenofovir/Emtricitabine (TDF/FTC) as backbone plus a third antiretroviral drug.

The patients had substantially different HDV and HBsAg loads before peg-IFN start, with \#A showing the highest values for both parameters. Treatment with TDF/FTC was initiated 10, 23 and 34 months before peg-IFN start (Table 1). An end of treatment response
(ETR) was observed in both \#B and \#C, but only \#C achieved a SVR, with HDV-RNA still undetectable three years after the end of peg-IFN administration. Interestingly, in $\mathrm{AC}$ the peg-IFN treatment lasted 12 months after achieving undetectable HDV-RNA, versus only 6 months in the relapser patient \#B.

Serum HBsAg levels substantially decreased $\left(>2 \log _{10}\right)$ during treatment in $\# \mathrm{C}$, whereas the relapser patient $\# \mathrm{~B}$ only experienced a slight decline $\left(<2 \log _{10}\right)$, that reverted after stopping treatment. By contrast, serum HBsAg levels did not show substantial modification during treatment in the non responder patient \#A (Table 2). HBe-Ag and $\mathrm{HBs}-\mathrm{Ab}$ remained negative in all three patients.

Pre-treatment CD4+T-cell count and liver histology seemed not to influence HDV-RNA clearance. None of the two patients with compensated liver cirrhosis experienced any sign of hepatic failure during peg-IFN course. The Fibroscan ${ }^{\circledR}$ liver stiffness was repeated in \#C one and three years after peg-IFN end, resulting in a slight but progressive decline (24.2 KPa pre-treatment vs 19.6 $\mathrm{KPa}$ and $14.6 \mathrm{KPa}$ respectively), suggesting a clinical benefit of achieving SVR.

\section{Discussion}

Few epidemiological data have been published on triple

Table 1. Clinical and demographic data of study patients at the moment of pIFN start.

\begin{tabular}{|c|c|c|c|c|c|c|c|c|c|c|}
\hline $\begin{array}{l}\text { Patient } \\
\text { ID }\end{array}$ & Age & $\begin{array}{l}\text { CDC } \\
\text { stage }\end{array}$ & $\begin{array}{c}\text { HIV } \\
\text { diagnosis } \\
\text { (year) }\end{array}$ & $\begin{array}{c}\text { Start } \\
\text { HAART } \\
\text { (year) }\end{array}$ & $\begin{array}{c}\text { Start } \\
\text { TDF/FTC } \\
\text { (m/year) }\end{array}$ & $\begin{array}{c}\text { Start peg-IFN/ } \\
\text { duration } \\
\text { (m/year)/(months) }\end{array}$ & $\begin{array}{c}\text { Third ARV } \\
\text { drug }\end{array}$ & $\mathrm{CD} 4 / \mathrm{mm}^{3}$ & $\begin{array}{l}\text { AST/ALT } \\
\text { (UI/ml) }\end{array}$ & $\begin{array}{c}\text { Liver fibrosis } \\
\text { stage (metavir) }\end{array}$ \\
\hline$\# \mathbf{A}$ & 41 & A3 & 1998 & 2003 & Jan 2006 & Oct $2006 / 18$ & $\mathrm{EFV}$ & 417 & $63 / 72$ & 2 \\
\hline \#B & 51 & B3 & 1985 & 1998 & Jun 2005 & Oct $2007 / 12$ & $\mathrm{LPV} / \mathrm{r}$ & 272 & $22 / 58$ & 4 \\
\hline \#C & 47 & B3 & 1990 & 2000 & Jan 2004 & Sep 2007/15 & $\mathrm{ATV} / \mathrm{r}$ & 233 & $77 / 140$ & 4 \\
\hline
\end{tabular}

Legend: peg-IFN: pegylated $\alpha 2$-Interferon; CDC: centers for disease control, Atlanta USA; HAART: highly active anti retroviral treatment; TDF/FTC: tenofovir/emtricitabine; EFV: efavirenz; LPV/r: lopinavir/ritonavir; ATV/r: atazanavir/ritonavir; CD4: circulating CD4+ lymphocytes; AST: aspartate transferase; ALT: alanine transferase.

Table 2. Virologic features during and after peg-IFN treatment.

\begin{tabular}{|c|c|c|c|c|c|c|c|c|c|c|c|c|c|c|c|c|c|}
\hline \multirow{2}{*}{ 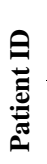 } & \multicolumn{2}{|c|}{ T0 } & \multicolumn{2}{|c|}{ T3 } & \multicolumn{2}{|c|}{ T6 } & \multicolumn{2}{|c|}{ T12 } & \multicolumn{2}{|c|}{$\begin{array}{c}\text { End of } \\
\text { Treatment }\end{array}$} & \multicolumn{2}{|c|}{$\begin{array}{l}6 \text { months } \\
\text { of follow-up }\end{array}$} & \multicolumn{2}{|c|}{$\begin{array}{l}12 \text { months of } \\
\text { follow-up }\end{array}$} & \multicolumn{2}{|c|}{$\begin{array}{l}24 \text { months of } \\
\text { follow-up }\end{array}$} & \multirow[t]{2}{*}{$\begin{array}{c}\text { HDV } \\
\text { Outcome }\end{array}$} \\
\hline & HDV & HBsAg & HDV & HBsAg & HDV & HBsAg & $\mathrm{HDV}$ & HBsAg & HDV & HBsAg & HDV & HBsAg & HDV & HBsAg & HDV & HBsAg & \\
\hline \#A & 8.2 & $>4.4$ & 7.4 & $>4.4$ & 7.1 & $>4.4$ & 5.7 & $>4.4$ & 3.2 & 4.3 & 5.3 & 2.9 & 7.7 & $>4.4$ & 8.1 & $>4.4$ & $\begin{array}{c}\text { Non } \\
\text { Response }\end{array}$ \\
\hline \#B & 7.6 & 3.6 & 5.3 & 3.2 & 2.8 & 3.0 & & $\rightarrow$ & $<2.6$ & 2.0 & $<2.6$ & 2.9 & 2.8 & 3.0 & 3.0 & 2.6 & $\begin{array}{l}\text { ETR- } \\
\text { Relapse }\end{array}$ \\
\hline \#C & 4.9 & 2.5 & 2.8 & 2.7 & $<2.6$ & $<0.1$ & $<2.6$ & $<0.1$ & $<2.6$ & 0.1 & $<2.6$ & 0.8 & $<2.6$ & 0.5 & $<2.6$ & 0.5 & SVR \\
\hline
\end{tabular}

HDV-RNA viral load is expressed as $\log _{10} \mathrm{HDV}$ RNA eq $/ \mathrm{ml}$, HBsAg as $\log _{10} \mathrm{IU} / \mathrm{ml}$. HCV-RNA and HBV-DNA were undetectable in all 23 serum samples. Legend: peg-IFN: pegylated $\alpha 2$-Interferon; T: month of peg-IFN treatment; ETR: end of treatment response; SVR: sustained virological response. 
$\mathrm{HIV} / \mathrm{HBV} / \mathrm{HDV}$ or quadruple HIV/HBV/HDV/HCV coinfection [1,9] while information on viral interplay, clinical courses or treatment outcomes is only referred to individual cases $[4,10,11]$.

Rosa et al. described in 2005 the first case of a patient triple co-infected with HIV/HBV/HDV, showing a sustained response to HDV after peg-IFN treatment [4]. A 26-year-old woman, with an advanced liver fibrosis (Metavir F3), received $1.5 \mathrm{mcg} / \mathrm{Kg} / \mathrm{W}$ of pegylated alpha- $2 \mathrm{~b}$ IFN treatment for 18 months. Qualitative HDV-RNA was measured by RT-PCR (sensitivity: 1000 copies $/ \mathrm{ml}$ ). Thirty-eight weeks after treatment discontinuation, HDVRNA was still undetectable suggesting persistent viral clearance.

The second published report is by Gozlan et al. [11]. The authors reported the complete resolution of a chronic hepatitis $\mathrm{B}$ and $\mathrm{D}$ in a quadruple $\mathrm{HIV} / \mathrm{HBV} / \mathrm{HDV} / \mathrm{HCV}$ co-infected man. The patient started an effective lamivudine-containing antiretroviral treatment six years before and its liver biopsy documented a Metavir F1 fibrosis stage. A combination therapy associating peg-IFN and ribavirin was initially given to treat HCV. The treatment was discontinued after 24 weeks due to lack of $\mathrm{HCV}$ response. Unfortunately, information on pre-treatment HDV-RNA was not available. The short course anti-HCV therapy had a rather unexpected effect on HBV infection, resulting in HBsAg clearance and HBsAb seroconversion. A peak of HDV-RNA $\left(9.3 \times 10^{6}\right.$ copies $/ \mathrm{ml}$ by real time PCR [5]) was observed in this patient after HBsAg had cleared from the serum, followed by stable clearance of HDV viremia.

Coinfections with multiple hepatitis viruses are associated with diverse patterns of reciprocal inhibition of viral replication. HDV has been frequently shown to suppress HBV and HCV replication in patients with triple infection $[12,13]$. However, it is not clear how many of these HCV-Ab+/HCV-RNA negative individuals have truly recovered from $\mathrm{HCV}$ infection or whether $\mathrm{HCV}$ is just suppressed in the context of viral coinfection. Indeed, our three patients were persistently HCV-RNA negative, even before IFN treatment. Both patients $\# \mathrm{~B}$ and $\mathrm{AC}$, who stopped HDV replication for at least 6 and 12 months, respectively, after peg-IFN end, did not experience any HCV-RNA rebound during this period, suggesting that in these cases HDV replication was not the direct cause of $\mathrm{HCV}$ inhibition.

Uncontrolled HIV-replication accelerates fibrosis progression in HCV and in HBV-coinfected subjects $[14,15]$. However, HAART appears to correct this faster progression only when HBV or HCV replication is suppressed by targeted antiviral treatment [16]. Our two cases with SVR and ETR, had liver cirrhosis and elevated liver enzymes at the beginning of peg-IFN course in 2007. Af- ter peg-IFN treatment, liver enzymes returned almost within the normal range in both patients and their clinical course is favorable until today, with no signs of liver failure or ALT rebound, supporting a possible delay in cirrhosis evolution. Interestingly, in the "relapser" patient \#B the post treatment HDV-RNA level remained substantially lower than the baseline one (5 $\log _{10}$ decline), even after 3 years, indicating a prolonged antiviral benefit despite viral relapse.

In HDV infection there is no proof that HDV-RNA load correlates with any clinical marker of activity or stage of liver disease. However, HDV-RNA and HBsAg levels are strictly associated in HDV chronic hepatitis [17]. In our study patients \#B and \#C showed HDV-RNA and HBsAg baseline levels significantly lower than patient \#A, who failed to clear serum HDV RNA, despite being younger and showing only initial signs of liver fibrosis. Thus, although observed in only three patients, it is tempting to hypothesize that baseline HDV-RNA level may be useful to predict the chance of viral response in HIV/HBV/HDV patients, when peg-IFN antiviral treatment is indicated.

Recent reports have suggested that the use of potent anti-HBV drugs, such as Tenofovir, could indirectly be beneficial against delta hepatitis, producing reductions in HDV replication and halting progression of liver fibrosis in HBV/HDV monoinfected patients [18]. An observational study of individuals coinfected with HIV/HBV/ HDV on long-term treatment including Tenofovir showed a slight decline in serum HDV-RNA after 6 years, suggesting that prolonged treatment with HBV inhibitors may lead to beneficial effects in patients with HDV, possibly owing to a reduction in serum HBsAg levels. Our three patients were all on combined TDF/FTC therapy before starting peg-IFN for a variable period of time (Table 1), probably too short to observe a relevant HDVRNA decrease.

Based on our small case-series, we suggest that also in $\mathrm{HIV}+$ patients, low baseline levels and substantial HDVRNA decline after 6 months of peg-IFN treatment may represent a good predictor of virological response. This finding may have potential clinical relevance, since, when pIFN treatment can be delayed, it seems reasonable to reduce HDV-RNA by TDF/FTC therapy to the lowest possible level, and to add peg-IFN thereafter.

\section{Conflict of Interest and Acknowledgements}

None of the authors disclose competing interests.

We thank Dr. Carla Nisii for critical review of the manuscript. This work was supported in part by grants from Italian Ministry of Health, Fondi Ricerca Corrente and Ricerca Finalizzata. 


\section{Ethical Approval}

This study was exempt from ethical review, since it was based on a retrospective chart review, and analyses were performed on an anonymized database. In this respect, the local policy was complying with the international policy recently reviewed [19], and with the current Italian legislation.

\section{REFERENCES}

[1] C. Castellares, P. Barreiro, L. Martín-Carbonero, P. Labarga, M. E. Vispo, R. Casado, L. Galindo, P. GarcíaGascó, J. García-Samaniego and V. Soriano, "Liver Cirrhosis in HIV-Infected Patients: Prevalence, Aetiology and Clinical Outcome," Journal of Viral Hepatitis, Vol. 15, No. 3, 2008, pp. 165-172.

[2] V. Soriano, E. Vispo, P. Labarga, J. Medrano and P. Barreiro, "Viral Hepatitis and HIV Co-Infection," Antiviral Research, Vol. 85, No. 1, 2010, pp. 303-315. doi:10.1016/j.antiviral.2009.10.021

[3] G. A. Niro, A. Ciancio, G. B. Gaeta, A. Smedile, A. Marrone, A. Olivero, M. Stanzione, E. David, G. Brancaccio, R. Fontana, F. Perri, A. Andriulli and M. Rizzetto, "pegylated Interferon Alpha-2b as Monotherapy or in Combination with Ribavirin in Chronic Hepatitis Delta," Hepatology, Vol. 44, No. 3, 2006, pp. 713-720. doi:10.1002/hep.21296

[4] I. Rosa, L. Costes, V. Garrait and M. Chousterman, "Efficacy of pegylated Interferon Alpha-2b for the Treatment of Chronic Delta Hepatitis in a Patient Co-Infected with HIV," AIDS, Vol. 19, No. 18, 2005, pp. 2177-2178. doi:10.1097/01.aids.0000194794.13305.08

[5] F. Le Gal, E. Gordien, D. Affolabi, T. Hanslik, C. Alloui, P. Dény and E. Gault, "Quantification of Hepatitis Delta Virus RNA in Serum by Consensus Real-Time PCR Indicates Different Patterns of Virological Response to Interferon Therapy in Chronically Infected Patients," Journal Clinical Microbiology, Vol. 43, No. 5, 2005, pp. 2363-2369. doi:10.1128/JCM.43.5.2363-2369.2005

[6] C. Castelnau, F. Le Gal, M. P. Ripault, E. Gordien, M. Martinot-Peignoux, N. Boyer, B. N. Pham, S. Maylin, P. Bedossa, P. Dény, P. Marcellin and E. Gault, "Efficacy of peginterferon Alpha-2b in Chronic Hepatitis Delta: Relevance of Quantitative RT-PCR for Follow-Up," Hepatology, Vol. 44, No. 3, 2006, pp. 536-539. doi:10.1002/hep. 21325

[7] E. K. Manesis, M. Schina, F. Le Gal, O. Angelopoulou, C. Papaioannou, C. Kalligeros, V. Arseniou, S. Manolakopoulos, E. S. Hadziyannis, E. Gault, J. Koskinas, G. Papatheodoridis and A. J. Archimandritis, "Quantitative Analysis of Hepatitis D Virus RNA and Hepatitis B Surface Antigen Serum Levels in Chronic Delta Hepatitis Improves Treatment Monitoring," Antiviral Therapy, Vol. 12, No. 3, 2007, pp. 381-388.

[8] A. Theamboonlers, T. Hansurabhanon, V. Verachai, V. Chongsrisawat and Y. Poovorawan, "Hepatitis D Virus Infection in Thailand: HDV Genotyping by RT-PCR, RFLP and Direct Sequencing," Infection, Vol. 30, No. 3, 2002, pp. 140-144. doi:10.1007/s15010-002-2061-X
[9] M. Buti, M. Homs, F. Rodriguez-Frias, G. Funalleras, R. Jardi, S. Sauleda, D. Tabernero, M. Schaper and R. Esteban, "Clinical Outcome of Acute and Chronic Hepatitis Delta over Time: A Long-Term Follow-Up Study," Journal of Viral Hepatitis, Vol. 18, No. 6, 2011, pp. 434442. doi:10.1111/j.1365-2893.2010.01324.x

[10] E. Polilli, F. Sozio, E. Mazzotta, A. Pieri, L. Alterio, E. Placido, A. Agostinone, F. Di Masi , M. Tontodonati, A. Consorte, L. Cosentino and G. Parruti, "Fatal Reactivation of HBV and HDV during a Long-Lasting Interruption of HAART in a Patient Co-Infected with HIV, HCV, HBV and HDV," Infez Med, Vol. 18, No. 1, 2010, pp. 4347.

[11] J. Gozlan, K. Lacombe, E. Gault, G. Raguin and P. M. Girard, "Complete Cure of HBV-HDV Co-Infection after 24 Weeks of Combination Therapy with Pegylated Interferon and Ribavirin in a Patient Co-Infected with HBV/ HCV/HDV/HIV," Journal of Hepatology, Vol. 50, No. 2, 2009, pp. 432-434. doi:10.1016/i.jhep.2008.05.029

[12] E. Sagnelli, N. Coppola, C. Scolastico, P. Filippini, T. Santantonio, T. Stroffolini and F. Piccinino, "Virologic and Clinical Expressions of Reciprocal Inhibitory Effect of Hepatitis B, C, and Delta Viruses in Patients with Chronic Hepatitis," Hepatology, Vol. 32, No. 5, 2000, pp. 1106-1110. doi:10.1053/jhep.2000.19288

[13] H. Wedemeyer and M. P. Manns, "Epidemiology, Pathogenesis and Management of Hepatitis D: Update and Challenges Ahead (Review)," Nature Reviews Gastroenterology \& Hepatology, Vol. 7, No. 1, 2010, pp. 31-40.

[14] Y. Benhamou, M. Bochet, V. Di Martino, F. Charlotte, F. Azria, A. Coutellier, M. Vidaud, F. Bricaire, P. Opolon, C. Katlama and T. Poynard, "Liver Fibrosis Progression in Human Immunodeficiency Virus and Hepatitis C Virus Coinfected Patients. The Multivirc Group," Hepatology, Vol. 30, No. 4, 1999, pp. 1054-1058. doi:10.1002/hep.510300409

[15] M. Núñez, B. Ramos, B. Díaz-Pollán, N. Camino, L. Martìn-Carbonero, P. Barreiro, J. González-Lahoz and V. Soriano, "Virological Outcome of Chronic Hepatitis B Virus Infection in HIV-Coinfected Patients Receiving Anti-HBV Active Antiretroviral Therapy," AIDS Research and Human Retroviruses, Vol. 22, No. 9, 2006, pp. 842-848. doi:10.1089/aid.2006.22.842

[16] P. Tuma, J. Medrano, S. Resino, E. Vispo, A. Madejòn, C. Sanchez-Piedra, P. Rivas, P. Labarga, L. Martín-Carbonero, P. Barreiro and V. Soriano, "Incidence of Liver Cirrhosis in HIV-Infected Patients with Chronic Hepatitis $\mathrm{B}$ or $\mathrm{C}$ in the Era of Highly Active Antiretroviral Therapy," Antiviral Therapy, Vol. 15, No. 6, 2010, pp. 881886. doi:10.3851/IMP1630

[17] K. Zachou, C. Yurdaydin, U. Drebber, G. N. Dalekos, A. Erhardt, Y. Cakaloglu, H. Degertekin, S. Gurel, S. Zeuzem, H. Bozkaya, V. Schlaphoff, H. P. Dienes, T. C. Bock, M. P. Manns and H. Wedemeyer, "HIDT-1 Study Group. Quantitative HBsAg and HDV-RNA Levels in Chronic Delta Hepatitis," Liver International, Vol. 30, No. 3, 2010, pp. 430-437. doi:10.1111/j.1478-3231.2009.02140.x

[18] J. Sheldon, B. Ramos, C. Toro, P. Rìos, J. MartinezAlarcòn, M. Bottecchia, M. Romero, J. Garcia-Sama- 
niego and V. Soriano, "Does Treatment of Hepatitis B Virus (HBV) Infection Reduce Hepatitis Delta Virus (HDV) Replication in HIV-HBV-HDV-Coinfected Patients?" Antiviral Therapy, Vol. 13, No. 1, 2008, pp. 97102.
[19] J. Millum and J. Menikoff, "Streamlining Ethical Review," Annal International Medecine, Vol. 153, No. 10, 2010, pp. 655-657.

\section{Abbreviations}

TDF/FTC: tenofovir/emtricitabine;

HBsAg: hepatitis B surface antigen;

IFN: interferon;

peg-IFN: pegylated alfa-2a interferon;

RT: reverse transcriptase;

KPa: kilo pascal. 